\title{
Fire Temperatures in Grass, Shrub and Aspen Forest Communities of Central Alberta
}

\author{
ARTHUR W. BAILEY AND MURRAY L. ANDERSON
}

\begin{abstract}
Soil surface temperatures averaged 186,398 and $393^{\circ} \mathrm{C}$ for grass, shrub and forest communities, respectively. Higher temperatures were associated with head fires, more fuel and with woody fuels. Temperatures in headfires were higher but more variable than in backfires for the three types of vegetation. The aspen forest was found to be the most difficult to obtain complete burn coverage. Headfires and backfires went out more readily in this type than in shrubland or grassland.

The aspen parkland of the Canadian prairies is a mosaic of grass, shrub and forest plant communities. In central Alberta, common plant communities include a rough fescue-western porcupine grass (Festuca scabrella ${ }^{1}$-Stipa spartea var. curtiseta) upland grassland interspersed with colonies of western snowberry (Symphoricarpos occidentalis) and forest communities dominated by aspen poplar (Populus tremuloides) (Fig. 1).

Fire was an important influence on vegetation prior to white settlement and was mainly caused by lightning and Indians (Nelson and England 1971). Brush cover in the central Alberta parklands ranged from about 5 to $10 \%$ in the early 1900's (Bailey and Wroe 1974; Scheffler 1976). Now, without periodic fires, brush cover ranges from about $10 \%$ in the drier parts of the parkland (Bailey and Wroe 1974) to 60 to $100 \%$ cover in the more mesic areas.

The quantity of fuel influences fire temperature (Smith and Sparling 1966; Stinson and Wright 1969) but the kind of fuel also influences temperature. Bentley and Fenner (1958) found that woody fuels burn hotter than grass fuels.

Fire temperature is usually highest a distance above ground. This distance varies with vegetation, fuel and weather

Authors are professor and research assistant, Department of Plant Science, University of Alberta, Edmonton, Alberta. The junior author is now supervisor, grazing reserves, central district, Lands Division, Alberta Department of Energy and Natural Resources.
Manuscript received September 22, 1978.

'Nomenclature follows Moss (1959).
\end{abstract}

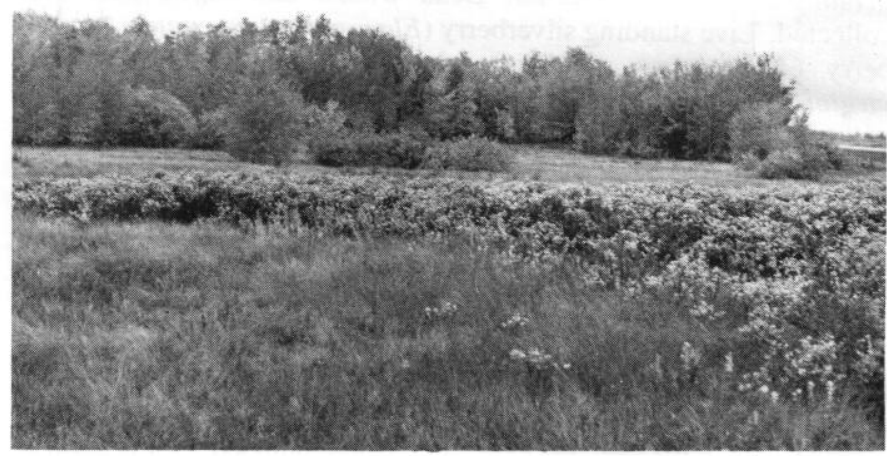

Fig. 1. A grassland of rough fescue-western porcupine grass, western snowberry shrubland and aspen forest in the central Alberta aspen parkland.

conditions and has been recorded at $5-15 \mathrm{~cm}$ (Probasco 1977), 5-20 cm (McKell 1962), 11- $17 \mathrm{~cm}$ (Iwanami 1969) and 5-30 $\mathrm{cm}$ (Iwanami 1972). Headfires usually raise the height of high temperatures but their duration is shorter than in backfires (Iwanami 1972). In woody vegetation, backfires frequently burn longer and deeper but headfires are hotter (Fahnestock and Hare 1964).

There is a growing interest in reintroducing fire into the aspen parkland as a range management tool. We have recently reported on the effect of fire on the grasslands (Bailey and Anderson 1978). Our main objective in this study was to determine the range in temperatures obtained during prescribed burning of the grass, shrub and aspen forest communities. Specific objectives were to determine: (1) fire temperatures at ground level in the three vegetation types; (2) the distribution of fire temperatures by position within stands of vegetation and in relationship to height above ground; (3) the effect of headfires versus backfires on fire temperatures; and (4) the relationship of fuels to fire temperature. 


\section{Methods}

Fuels

Fuels were collected from grassland and shrubland in April, 1971 and 1972, and from aspen forest in May, 1977. All burnable materials were collected, ovendried and weighed. In the shrubland and forest this included the $\mathrm{L}$ and the dry part of the F layers. All plots were located in a stratified random manner.

Four stands were randomly selected in the grassland and another four stands in the shrubland in 1971 . Fifteen $20 \times 50 \mathrm{~cm}\left(0.1 \mathrm{~m}^{2}\right)$ plots/stand were randomly located and total dry fuel was collected.

Three stands of shrubland and adjacent grassland were sampled in May 1972. Two belt transects radiated from the center of the shrub stand to $20 \mathrm{~m}$ into the adjacent grassland. Both the shrub portion and the grass portion of each transect was divided into thirds and a $0.1 \mathrm{~m}^{2}$ fuel sample was collected in each. A total of 18 fuel plots were collected in the shrubland and 18 in the grassland. The dry fuels were collected and separated into (a) grass, (b) other ground surface fuels, and (c) standing woody. The density of snowberry stems was also determined.

Forest fuels were sampled in six aspen groves. Two belt transects radiated from the center of each grove. Each transect was subdivided into six segments and one $50 \times 100 \mathrm{~cm}\left(0.5 \mathrm{~m}^{2}\right)$ fuel plot placed in each segment. The two plots near the center of each grove were located in the aspen-willow community, the next two in large aspen and the outer two in the small aspen community following the classification of Hilton and Bailey (1974). All dry fuels were collected and separated into (a) ground surface fuels, and (b) standing woody fuels. Experience developed through 10 years of burning aspen forests was relied upon to identify standing fuels that would burn. All standing shrubs of western snowberry, wild rose (Rosa acicularis, $R$. woodsii), wild raspberry (Rubus strigosus) and wild gooseberry (Ribes oxyacanthoides) were collected. Dead willow and aspen were also collected. Live standing silverberry (Elaeagnus commutata), serviceberry (Amelanchier alnifolia), cherry (Prunus pensylvanica, $P$. virginiana), aspen poplar and green stems of willow were not collected because they usually do not burn.

\section{Fire temperatures}

1971

Fire tempcraturc cards were located in four grassland stands and four shrub stands. In each stand, fifteen metal posts were randomly located within a $15 \mathrm{~m}^{2}$ area. Pyrometers (asbestos cards) measuring 4 $\times 4 \times 1 / 16$ inches were attached to each post at $0,5,15,30,45 \mathrm{~cm}$ in the grassland and $0,8,20,45$ and $75 \mathrm{~cm}$ in the shrub community. Commercial temperature pellets that melt at specific temperatures were placed on the asbestos card and covered with a $0.25 \mathrm{~mm}$ sheet of mica. For the grassland, temperature pellets were used that melted at $66,93,121,149,177,232,260,288$ and $343^{\circ} \mathrm{C}$. For the shrubland, temperature pellets were used that melted at $177,232,260,288,315$, $343,371,399,427,454,482,538,593$ and $648^{\circ} \mathrm{C}$. A $20 \mathrm{X}$ binocular microscope was used to determine the highest temperature pellet that had melted. In the 1971 grassland burns, the maximum measurable temperature at $343^{\circ} \mathrm{C}$ was exceeded $1,2,3$ and 1 times at the heights of $0,15,30$ and $45 \mathrm{~cm}$, respectively. In the shrubland, the maximum measurable temperature at $648^{\circ} \mathrm{C}$ was exceeded $4,9,10,3$ and 1 times at the heights of $0,8,20,45$ and $75 \mathrm{~cm}$, respectively.

\section{2}

Fire temperature cards were identical to those used in 1971 except that $371,427,482$ and $538^{\circ} \mathrm{C}$ temperature pellets were added to those used in the grassland and $704,760,816,871,927,982$ and $1371^{\circ} \mathrm{C}$ were added to those used in the shrubland and forest. Temperature cards were located $0.5 \mathrm{~m}$ from the fuel collection plots. In the forest, the sampling design was identical to that of the shrubland.

\section{Results}

The grassland had the lowest ground surface fire temperatures and the least fuel (Table 1). Fuel moisture averaged $16 \%$ in the grassland and $20 \%$ in shrubland. Fire temperatures were
Table 1. Fire temperature $\left({ }^{\circ} \mathrm{C}\right)$ and available fuel $(\mathrm{kg} / \mathrm{ha})$ in three vegetation types.

\begin{tabular}{lccc}
\hline & & \multicolumn{2}{c}{ Vegetation Type } \\
\cline { 2 - 4 } Character & Grassland & Shrubland & Forest \\
\hline Fire temperature & $186 \pm 10^{1}$ & $398 \pm 16$ & $393 \pm 28$ \\
Total fuel & $5,085 \pm 334$ & $18,255 \pm 1,551$ & $13,436 \pm 354$ \\
Ground fuel & $3,929 \pm 294$ & $7,237 \pm 539$ & $11,704 \pm 337$ \\
Standing woody & $657 \pm 311$ & $11,017 \pm 1,352$ & $1,732 \pm 181$ \\
$\quad$ fuel & & & 53 \\
$\begin{array}{l}\text { Area burned in } \\
\quad 1972(\%)\end{array}$ & 90 & 100 & 5 \\
\hline
\end{tabular}

' Standard error of the mean

about the same in the shrub and aspen forest communities. There was more total fuel in the shrubland than in the forest. The difference was primarily due to the abundance of standing western snowberry stems in the shrubland. The quantity of ground level fuel increased steadily from the grassland through the shrubland to the forest. Both grassland and shrubland burned readily in the 330 ha fire of 1972 but only half the aspen forest burned.

Fire temperatures were related to fuels in grassland-shrubland transects (Fig. 2). Grassland has less total fuel, less woody fuel and lower fire temperatures.

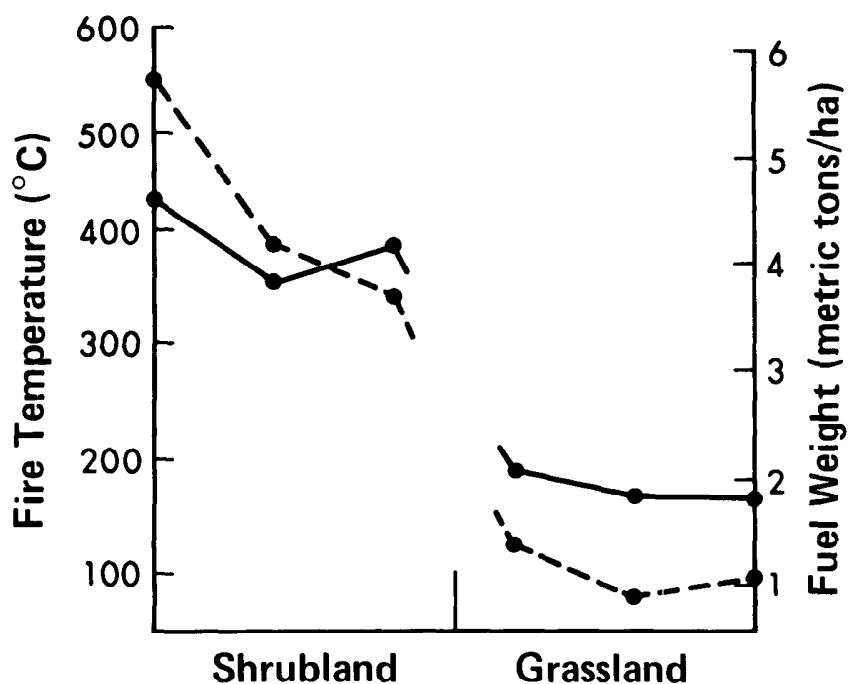

Fig. 2. Relationship of fire temperature $\left({ }^{\circ} \mathrm{C}\right)(-)$ to fuel weight (metric tons/ha) (--) from the center of a shrub stand (left to the center of the grassland (right).

Total fuels were greater near the center of shrub stands due to the higher density of snowberry stems (Table 2). Fire temperatures were also higher near the center of shrub colonies. Total fuels were similar in the three positions in the aspen forest. There was more standing woody fuel, mostly western snowberry, in the small aspen type near the margin of groves. There was also a correspondingly less quantity of ground surface fuels at the grove margin.

Both backfires and headfires occurred in the three vegetation types (Table 3). Fire temperatures were significantly higher in headfires than in backfires. The greatest range of fire temperatures occurred in the aspen forest. This community was the most difficult to burn and backfires usually went out.

Closer relationships were found between fire temperature and fuel components on grass-shrub transects when only areas burned by headfires were considered. The following multiple regression equation accounted for $66 \%$ of the variation and the 
Table 2. Distribution of fuels $(\mathrm{kg} / \mathrm{ha})$ in shrub stands and aspen groves.

\begin{tabular}{|c|c|c|c|}
\hline \multirow{2}{*}{$\begin{array}{l}\text { Type of fuel } \\
\text { and vegetation }\end{array}$} & \multicolumn{3}{|c|}{ Position in Stand } \\
\hline & Inner $1 / 3$ & Middle $1 / 3$ & Outer $1 / 3$ \\
\hline Snowberry shrubland & $25,173 \mathrm{a}^{1}$ & $16,857 \mathrm{ab}$ & $14,732 b$ \\
\hline $\begin{array}{l}\text { Standing woody } \\
\text { fuel }\end{array}$ & $14,906 a$ & $9,349 b$ & $8,798 b$ \\
\hline Ground surface fuel & $18,270 a$ & $7,508 \mathrm{a}$ & $6,270 \mathrm{a}$ \\
\hline $\begin{array}{l}\text { Fire temperature } \\
\left({ }^{\circ} \mathrm{C}\right)\end{array}$ & $445 a$ & $368 b$ & $381 b$ \\
\hline Aspen forest & & & \\
\hline $\begin{array}{l}\text { Total fuel } \\
\text { Standing woody }\end{array}$ & $12,671 \mathrm{a}$ & $13,970 \mathbf{a}$ & $13,699 \mathrm{a}$ \\
\hline $\begin{array}{l}\text { fuel } \\
\text { Ground surface }\end{array}$ & $644 b$ & $1,195 b$ & $3,361 \mathbf{a}$ \\
\hline $\begin{array}{l}\text { fuel } \\
\text { Fire temperature }\end{array}$ & $12,028 \mathrm{a}$ & $12,775 \mathfrak{a}$ & $10,308 b$ \\
\hline$\left({ }^{\circ} \mathrm{C}\right)$ & $407 a$ & $366 a$ & $413 a$ \\
\hline
\end{tabular}

Means followed by the same letter in horizontal sequence are not significantly different $(P<0.05)$ according to Duncan's multiple range test.

multiple correlation $(R=0.81)$ was significant $(P<0.01)$ : $\mathrm{Y}=340+21.6 \mathrm{X}_{1}-7.9 \mathrm{X}_{2}$

where $\mathrm{Y}=$ fire temperature $\left({ }^{\circ} \mathrm{C}\right)$

$\mathrm{X}_{1}=$ density of standing live and dead western snowberry stems (no. $/ 0.1 \mathrm{~m}^{2}$ )

$\mathrm{X}_{2}=$ grass fuel $\left(\mathrm{gm} / 0.1 \mathrm{~m}^{2}\right)$

The $t$-test on the slope $\mathrm{b}$ was significant for each variable. In the area studied, both shrubland and grassland always had snowberry stems. The higher the density of snowberry stems, the hotter the fire. Where there were fewer snowberry stems, there was more grass fuel and the fire temperatures were lower.

The fire temperature measured was affected by distance above ground (Fig. 3). In the grassland, the hottest temperatures were recorded at about $15 \mathrm{~cm}$ above ground in a headfire and at 5 $\mathrm{cm}$ above ground in a backfire. In the shrubland the hottest position was at $8 \mathrm{~cm}$ above ground in a backfire while it ranged from 8 to $20 \mathrm{~cm}$ above ground in the headfires. Fire temperatures were more variable within the shrub canopy than at ground level. At most distances above ground, headfire temperatures were more variable than those of backfires.

\section{Discussion}

The range of fire temperatures observed was as diverse as the vegetation in the aspen parkland. The primary factors influencing fire temperatures included kind, quantity and spatial distribution of fuels, weather conditions prior to and during burning, microrelief and type of fire.

Table 3. Mean fire temperature $\left({ }^{\circ} \mathrm{C}\right)$ at the soil surface, range in temperature, and area burned $(\%)$ for backfires and headfires, in three vegetation types in 1972 .

\begin{tabular}{llll}
\hline & \multicolumn{3}{c}{ Vegetation Type } \\
\cline { 2 - 4 } Mean temperature & Grassland & Shrubland & Forest \\
\hline Backfire & $137 \pm 9^{1}$ & $325 \pm 19$ & $228 \pm 32$ \\
Headfire & $206 \pm 12$ & $435 \pm 17$ & $430 \pm 29$ \\
Range & & & \\
$\quad$ Backfire & $93-232$ & $204-427$ & $93-371$ \\
$\quad$ Headfire & $93-427$ & $232-704$ & $260-982$ \\
Area Burned (\%) & & & \\
$\quad$ Backfire & 69 & 100 & 29 \\
$\quad$ Headfire & 95 & 100 & 65 \\
\hline
\end{tabular}

'Standard error of the mean

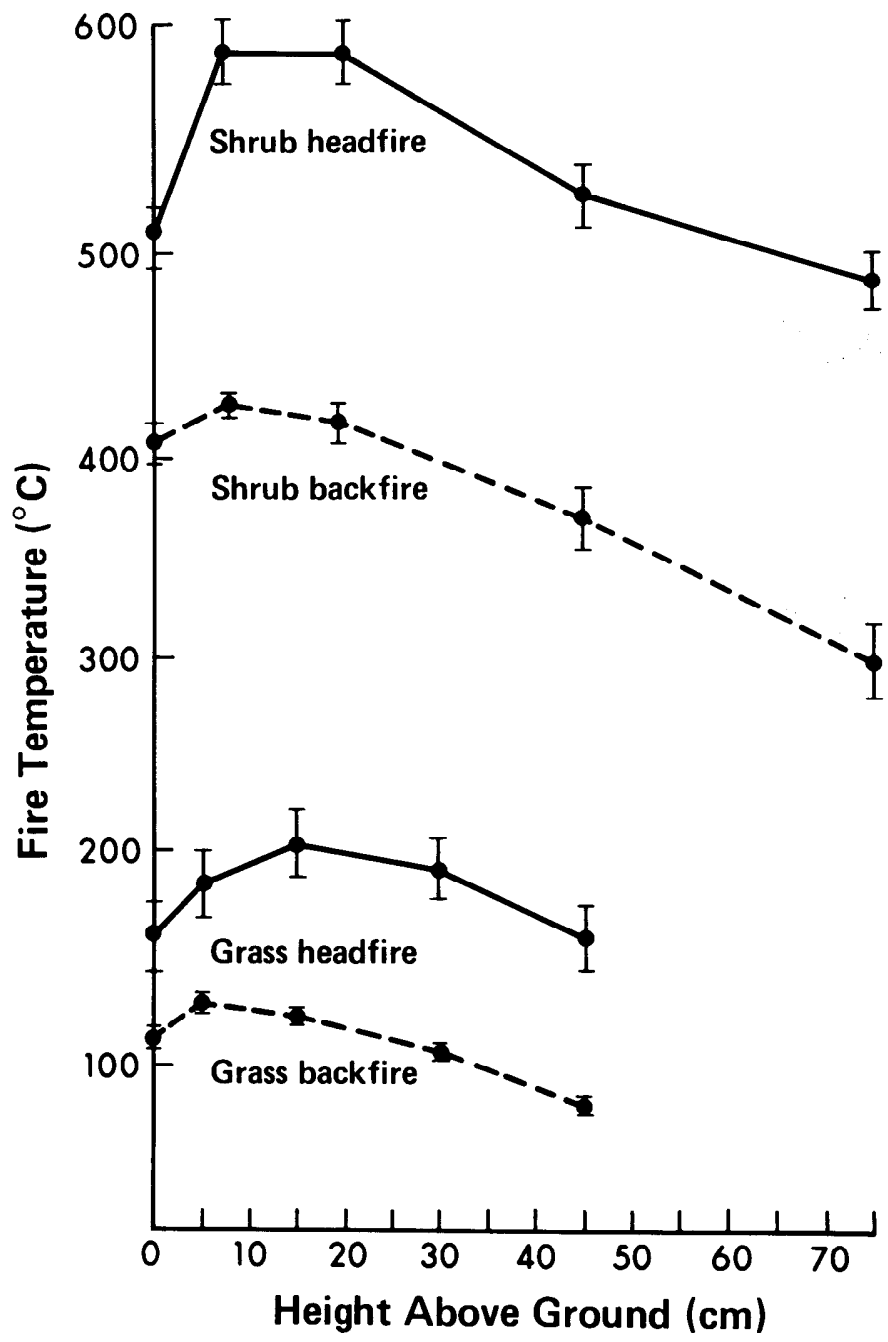

Fig. 3. Relationship of fire temperature $\left({ }^{\circ} \mathrm{C}\right)$ to height above ground $(\mathrm{cm})$ in grassland and shrubland. Vertical lines indicate the standard error of the mean

The grasslands burned rapidly but at comparatively low temperatures. The temperatures we observed were comparable to those found by other researchers burning similar quantities of fuel (i.e. McKell 1962; Iwanami and lizumi 1966; Stinson and Wright 1969). In his review, Daubenmire (1968, p 256) concluded that grassland backfires were hotter and produced their maximum temperatures nearer the ground, in comparison with headfires. In our study, headfires were hotter than backfires in all three vegetation types, while backfires had maximum temperatures nearer the ground.

The shrubland and aspen forest burned at higher temperatures than the grassland. On grass-shrub transects, the major factor influencing fire temperature was density of standing live and dead western snowberry stems. Fire temperatures achieved were similar to those obtained by Bentley and Fenner (1958) and Lawrence (1966) in chaparral and Whittaker (1961), Kenworthy (1963) and Kayll (1966) in heather and by Fahnestock and Hare (1964) in ground fires under pine forests.

Most of our recordings of fire temperature were made at the ground surface. We found, however, that the mean maximum temperature in grass or shrub types was consistently higher a distance above ground.

Fire temperatures were higher and fuels were greater near the center of western snowberry shrub stands. There was a greater abundance of standing live and dead shrub stems. The centers of 
western snowberry stands are the oldest and the rhizomes outlive the stems (Pelton 1953). This results in an accumulation of dead stems, most of which remain standing. The heather (Calluna v'ulgaris) in Scotland has a similar build up of dead stems as the stand becomes decadent (Kayll 1966; Gimingham 1971). Kenworthy (1963) found higher fire temperatures in old heather stands than in younger stands.

Fire temperatures were so variable in the aspen forest that it was difficult to relate them to probable causal factors. Backfires usually burned poorly, frequently going out within a few feet of ignition. The maximum temperature was only $288^{\circ} \mathrm{C}$ in a backfire. Fahnestock and Hare (1964) found that backfires burned longer and deeper in the pine forests of the southeastern United States. This was not the case in the aspen forest. The temperatures of headfires in aspen forests were hotter than in backfires but variability was high. Most temperatures recorded in headfires were in the $371-482^{\circ} \mathrm{C}$ range but $14 \%$ were in excess of $600^{\circ} \mathrm{C}$. This was related to the distribution of fuels and to weather conditions prior to and during burning. Aspen groves in the parkland were young with stems near the center averaging 20 to 22 years old and 2 to 13 years old at the margin (Scheffler 1976). Decadent or dead willows (Salix spp.), accumulated piles of dry, rotten aspen branches and logs and dense stands of western snowberry near the stand margin can all produce fire temperatures at the soil surface in excess of $600^{\circ} \mathrm{C}$.

Thermocouples usually record higher fire temperatures than do temperature pellets, paints or chemicals (Whittaker 1961; Kenworthy 1963; Stinson and Wright 1969). The maximum fire temperatures recorded in Texas at the soil surface averaged $13 \%$ higher with thermocouples than with temperature pellets (Stinson and Wright 1969).

A reasonable approximation of the lethal temperature for leaf tissue is $60^{\circ} \mathrm{C}$ (Daubenmire 1968, p 233). All fire temperatures recorded were above this level. Duration of high temperature was not measured and it is also of importance. Nevertheless, a period of time would be required for the heat to penetrate through the mica on our temperature cards and melt the temperature pellets. Inspite of these high temperatures, rough fescue and several other grasses initiated green shoots that become conspicuous on burned grassland about a week after the fire. In spring, the wet or frozen duff layer and mineral soil apparently dissipated heat effectively, preventing the penetration of lethal temperature levels into growing points near the mineral soil surface. Late spring burning after the soil surface had become dry would probably damage many grass tillers since the duff layers would burn down to mineral soil.

Fire temperatures were high enough in shrubland and aspen forest to consume all standing stems of western snowberry. On the other hand, aspen forests were hard to burn. A successful prescribed burn in aspen required very dry surface fuels, low relative humidity and winds in excess of $6 \mathrm{kph}$. An effective fire in aspen burned down most dead trees and high temperatures from the head fires resulted in nearly $100 \%$ mortality of aspen trees. The few survivors were usually protected from fire by unfavorable topographic relief.

The effect of high temperatures in forest or shrubland on perennial grasses, sedges and forbs is not known. Considerable mortality could be expected under dry soil conditions. When burning is conducted, in spring however, these soils are wet or frozen and ground fuels in contact with mineral soil are wet and usually do not burn. This wet litter probably protects the crowns of many perennial herbaceous plants from the high fire temperatures that occur a few centimeters above. However, directly below logs and willow clumps, where long periods of high fire temperatures are experienced, all of the litter layer is burned exposing mineral soil. The crowns of few herbaceous plants could be expected to survive such temperature conditions.

\section{Literature Cited}

Bailey, A.W. and M.L. Anderson 1978. Effect of fire on grassland in central Alberta. J. Range Manage. 31(6): 446-449.

Bailey, A.W. and R.A. Wroe 1974. Aspen invasion in a portion of the Alberta parklands. J. Range Manage. 27:263-266.

Bentley, J. and R.L. Fenner 1958. Soil temperatures during burning related to postfire seedbeds on woodland range. J. For. 56: 737-740.

Daubenmire, R. 1968. Ecology of fire in grasslands. p 209-266. In Cragg, J.B. Advances in Ecological Research, Vol. 5. Academic Press, London.

Fahnestock, G.R. and R.C. Hare 1964. Heating of tree trunks in surface fires. J. For. 62: 799-805.

Gimingham, C.H. 1971. British heathland ecosystems: the outcome of many years of management by fire. Tall Timbers Fire Ecol. Conf. 10: 293-321.

Hilton, J.E. and A.W. Bailey 1974. Forage production and utilization in a sprayed aspen forest in Alberta. J. Range Manage. 27: 375-380.

Iwanami, Y. 1969. Temperatures during Miscanthis type grassland fires and their effect on the regeneration of Miscanthus Sinensis. Rep. Inst. Agr. Res. Tohoku Univ. 20: 47-88.

Iwanami, Y. 1972. Burning temperatures of grasslands in Japan (4). Burning temperatures in Sasa type grasslands. Japan J. Ecol. 22:24-33.

Iwanami, Y. and S. Iizumi 1966. Report on the burning temperatures of Japanese lawn grass (Zoisia japonica Steud). Jap. J. Ecol. 16:40-41.

Kayll, A.J. 1966. Some characteristics of heath fires in north-east Scotland. J. App. Ecol. 3: 29-40.

Kenworthy, J.B. 1963. Temperatures in heather burning. Nature 200: 1226.

Lawrence, G.E. 1966. Ecology of vertebrate animals in relation to chaparral fire in the Sierra Nevada foothills. Ecology 47:278-291.

McKell, C.M., A.M. Wilson and B.L. Kay 1962. Effective burning of rangelands infested with medusahead. Weeds 10: 125-131.

Moss, E.H. 1959. Flora of Alberta. Univ. Toronto Press, Toronto. 546 p.

Nelson, J.G. and R.E. England 1971. Some comments on the causes and effects of fire in the northern grassland area of Canada and the nearby United States, CA. 1750-1900. Can. Geog. 15: 295-306.

Pelton, J. 1953. Studies on the life-history of Symphoricarpos occidentalis Hook in Minnesota. Ecol. Monogr. 23: 17-39.

Probasco, G.E. 1977. Tall fescue response to fire. USDA Forest Service, Res. Note $\mathrm{NC}-218,3 \mathrm{p}$.

Scheffler, E.J. 1976. Aspen forest vegetation in a portion of the east central Alberta parklands. Univ. Alberta M.Sc. thesis, Edmonton. 160 p.

Smith, D.W. and J.H. Sparling 1966. The temperatures of surface fires in Jack Pine barren. Can. J. Bot. 44: 1285-1298.

Stinson, K.J. and H.A. Wright 1969. Temperatures of headfires in the southern mixed prairie of Texas. J. Range Manage. 22: 169-174. Whittaker, E. 1961. Temperatures in heath fires. J. Ecol. 49: 709-715. 